\title{
Globalisation, Unemployment, and Poverty: The Need for a New Perspective on Social Protection in Malaysia
}

\author{
A.H. ROSLAN \\ M.M. MUSTAFA \\ Faculty of Economics \\ University Utara Malaysia
}

\begin{abstract}
The integration of an economy to the global market, even when it leads to a higher standard of living, usually results in economic uncertainties and insecurity, as well as eroding social values and traditions of the society. Some people may gain, while some others may lose out from it, which may cause distributive conflicts to emerge. The economic uncertainties and insecurity, as well as the distributive conflicts that arise from globalisation, could disrupt the economy from securing the benefits of globalisation, and

consequently could pose an impediment to economic growth. Hence, some scholars has argued that globalisation also increases the demand for greater role of government to stabilise the economy in terms of providing adequate social protection, if the benefits from globalisation are to be realised. This paper attempts to examine the impact of globalisation on the welfare of the Malaysian society, particularly on unemployment and poverty, and discusses the issues and challenges with regards to the provision of social protection in Malaysia. The paper argues that Malaysia needs a new perspective on social protection, as the existing institutions are deemed inadequate in providing protection to the society in the globalised economy.
\end{abstract}

\footnotetext{
ABSTRAK

Walaupun integrasi sesebuah ekonomi ke dalam pasaran global boleh meningkatkan taraf hidup, namun ia juga boleh membawa kepada ketidakpastian dan ketidakstabilan ekonomi serta menghakis tradisi dan nilai-nilai sosial sesebuah masyarakat. Globalisasi juga boleh mencetuskan konflik kerana sesetengah kumpulan dalam masyarakat mendapat untung daripada globalisasi, manakala sebahagian lagi mengalami kerugian. Ketidakpastian dan ketidakstabilan ekonomi serta konflik yang wujud akibat daripada globalisasi boleh mengganggu ekonomi daripada memperoleh faedah daripada globalisasi dan juga akan menjadi penghalang kepada pertumbuhan ekonomi. Oleh yang demikian terdapat sarjana yang menghujah bahawa globalisasi akan meningkatkan permintaan kepada kerajaan untuk memainkan peranan yang lebih besar dalam menstabilkan ekonomi dengan menyediakan perlindungan sosial yang sesuai dengan cabaran globalisasi yang dihadapi. Artikel ini cuba melihat kesan globalisasi ke atas kebajikan masyarakat Malaysia, khususnya berkaitan pengangguran dan kemiskinan, dan membincangkan isu-isu dan cabaran berkaitan penyediaan perlindungan sosial di Malaysia. Hujah artikel ini ialah satu perspektif baru terhadap perlindungan sosial di Malaysia adalah perlu kerana institusi-institusi yang sedia ada tidak cukup luas dalam menyediakan perlindungan sosial dalam ekonomi yang bersifat global.
} 


\section{INTRODUCTION}

It is often argued that globalisation ${ }^{1}$ leads to higher overall living standards of a nation and that global economic integration represents a vehicle for achieving significant economic growth and development. However, globalisation delivers both benefits as well as risks. As a result, even though the integration of an economy to the global market could result in higher living tandards, it also simultaneously exposes the economy to the external risks. Consequently, globalisation could result in economic instability and uncertainty. For instance, an economy could experience sudden and often drastic fluctuations of income and consumption as a result of their openness to volatile global capital inflows and outflows. Crises arising from globalisation, such a. the Asian financial crisis, usually have adverse effects of lower economic growth, decline in value of currencies, rising inflation and unemployment, displaced labour, and increase poverty.

Furthermore, globalisation also raises cial tensions and conflicts within the society the integration of an economy to the global market usually results in some people gaining while others losing out. This distributive conflicts as well as the economic instability arising from globalisation could disrupt the economy from securing the benefits of globalisation, and it could ose as an impediment to economic growth and levelopment. Hence, globalisation brings about a ignificant impact on poverty and unemployment. - Ttis for these reasons, Rodrik (1997; 1998) pointed out that globalisation increases the demand for greater role by the government to stabilise the conomy in terms of providing adequate social protection $^{2}$, if the benefits from globalisation are to be realised. Adequate and efficient institutions with regard to social protection are important not only to provide some income support to those who are losing out from the globalisation process, but also allow the economy to compete better in the global economy. Firms for instance, need to have the flexibility in hiring and firing workers if they want to be competitive and efficient in the global market. However, while giving firms this flexibility, those being fired need to be assisted and ensured that they have proper and sufficient social protection to survive. Thus, the provision of an adequate and efficient social protection system would help an economy to enhance its competitiveness.

This paper examines the impact of globalisation on the welfare of the Malaysian society, particularly on poverty and unemployment. It also examines the adequacy of existing institutions in Malaysia to protect society from the adverse impacts of globalisation. The paper highlights the need for a new perspective and thinking on social protection in Malaysia, as the current institutions are inadequate for the changing needs of the Malaysian society in the globalised economy. This paper is organised as follows. Section II discusses the background of the Malaysian economy, and Section III briefly reviews social protection in Malaysia. Section IV examines the impact of globalisation on unemployment and poverty, while Section V discusses issues and challenges arising from globalisation and the need for a new thinking on social protection in Malaysia. Section VI concludes the paper.

\section{OPENNESS OF THE MALAYSIAN ECONOMY}

Malaysian economy could be considered as an open economy. As a result, one of the serious challenges faced by the Malaysian economy is globalisation and the intensification of international competition. The openness of the economy, measured as the ratio of trade to GDP, has increased significantly in the last two decades (Table 1).

Besides, throughout the years, Malaysia has been able to sustain her economic growth by relying on foreign direct investment (FDI). Indeed, FDI has been the engine of the manufacturing sector's growth and export expansion. With the exception of Singapore, the inflow of FDI as a percentage of gross fixed capital formation in Malaysia is greater than other ASEAN countries (Table 2). 


\section{Table 1}

Malaysia's Economic Openness as Measured by the Ratio of Trade (Export + Import) to GDP in Nominal Values

\begin{tabular}{ccccc}
\hline Year & Export & Import & GDP & Openness $(\%)$ \\
\hline 1970 & 5,416 & 4,896 & 12,533 & 82.28 \\
1980 & 30,814 & 29,508 & 53,366 & 113.03 \\
1990 & 88,675 & 86,241 & 119,081 & 146.89 \\
2000 & 427,003 & 358,529 & 342,157 & 229.58 \\
2001 & 389,256 & 327,765 & 334,589 & 214.30
\end{tabular}

Sources: (i) Bank Negara Malaysia (1994) (ii) Ministry of Finance (Various Issues), Economic Reports.

Table 2

Inflow of Foreign Direct Investment as a Percentage of Gross Fixed Capital Formation

\begin{tabular}{ccccccc}
\hline Year & Malaysia & Singapore & Indonesia & Thailand & Philippines & South Korea \\
\hline 1970 & 13 & 15 & 7 & 3 & -0 & 3 \\
1980 & 12 & 26 & 1 & 3 & -1 & 0 \\
1990 & 18 & 47 & 3 & 7 & 5 & 1 \\
1995 & 15 & 41 & 8 & 3 & 10 & 1 \\
2000 & 17 & 46 & -14 & 12 & 10 & 7 \\
\hline
\end{tabular}

Source: UNCTAD (Various Issues), World Investment Report (http://www.unctad.org)

The government is also committed to the ASEAN Free Trade Area (AFTA), where the degree of protection in the economy will be reduced quite significantly. Under AFTA, import duties will be reduced to a maximum of $5 \%$ for most products from ASEAN countries to Malaysia. Furthermore, since 1987, the government has been implementing liberalisation and privatisation policies as a response to the growing fiscal difficulties experienced by the government. The government aggressively encouraged the private sector to take the leading role in economic growth and development of the country, and at the same time downsizing the size of the public sector in the economy. Thus, since mid-1980s, the Malaysian economy has become more integrated with the global market, with the private sector leading the way.

As an open economy, Malaysia is very much affected by global factors. Since 1970, there were four periods where the Malaysian economy had been affected badly by global fluctuations (Figure 1). The first was in 1975, when the world economy was hit by the oil crisis. During this crisis, Malaysian economic growth plunged from $8.3 \%$ in 1974 to $0.8 \%$ in 1975 . The second was in the 1985-1986 period, due to the world economic recession that caused major world commodity prices, such as rubber and palm oil, to fall significantly. Malaysian economic growth plunged from $7.8 \%$ in 1984 to $-1.1 \%$ in 1985 and $1.2 \%$ in 1986.

The third was the financial crisis in 199798, when the Malaysian economy was badly hit. Economic growth was $7.5 \%$ in 1997 , but it plunged dramatically to $7.5 \%$ in 1998 . The fourth was in 2001 when the world was facing the threat of terrorism after the September 11 attack on the World Trade Center in New York and also the threat of SARS. The economic growth plunged from $8.3 \%$ in 2000 to $0.4 \%$ in 
2001. Nonetheless, despite these negative external factors, the economy managed to grow at an average annual growth rate of more than $5.0 \%$ between 1960-2000. In fact, between 1988 and 1997 , the economy grew at a sustained annual average rate of more than $8.0 \%{ }^{3}$

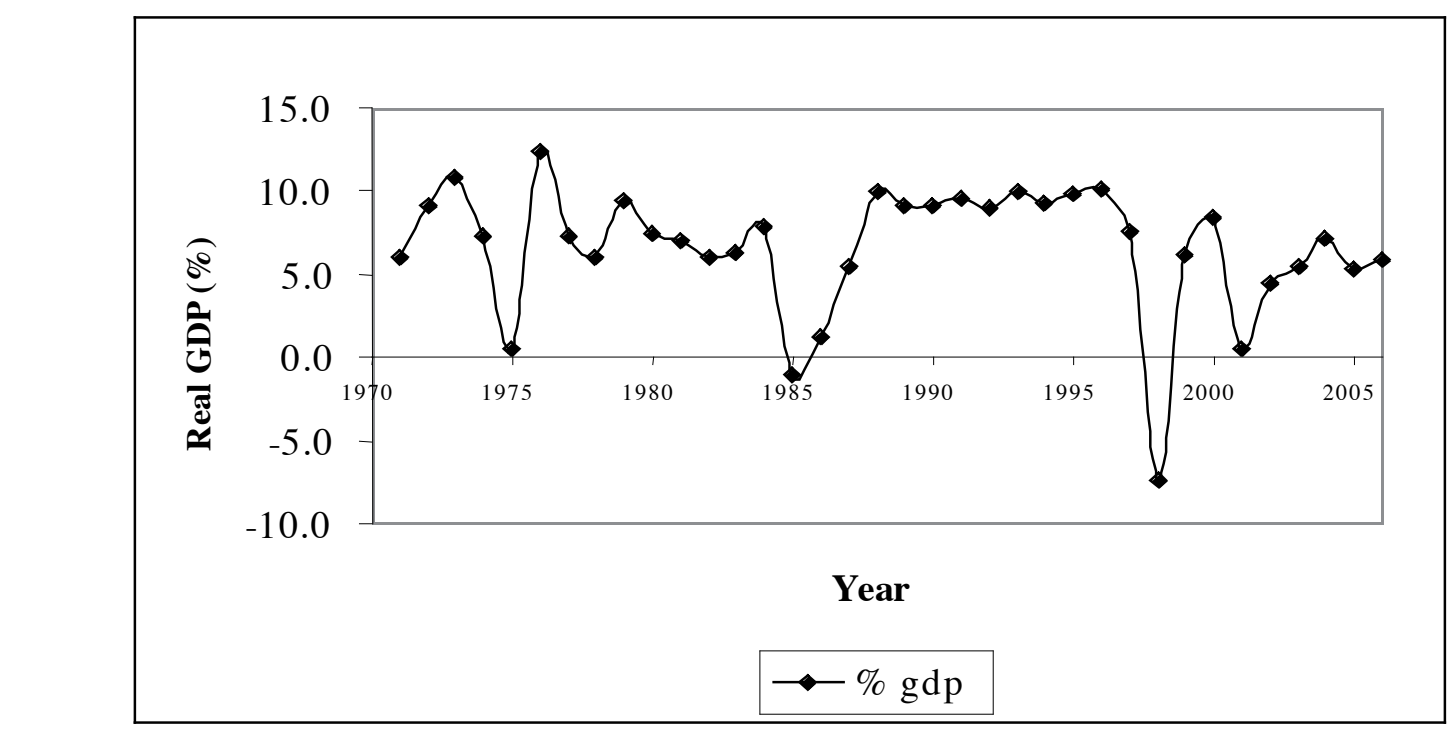

Source: Ministry of Finance (Various Issues), Economic Report.

Figure 1

Malaysia's real growth rates

SOCIAL PROTECTION IN MALAYSIA

Holzmann and Jorgensen (2000) defined social protection as consisting of public interventions (1) assist individuals, households, and ommunities better manage risk; and (2) provide support to the critically poor. Basically, they looked at social protection in terms of Social Risk Management (SRM). Their main idea was that all individuals, households, and communities are vulnerable to multiple risks from different sources, whether they are natural (such as earthquakes, flooding, and illness) or man-made (such as unemployment, environmental degradation, and war) risks. SRM is the development of strategies that include the prevention, mitigation, and coping mechanisms towards risks and vulnerability. It appears that, Holzmann and Jorgensen's (2000) definition of social protection is more comprehensive as compared to the current perception of social protection. Social protection from their perspective might consist of any set of public interventions that can lessen the impact of adverse shocks on the income of the population. These interventions may include labour market interventions, social safety nets, and pensions. It may also include public actions aimed at reducing risk, such as prudent fiscal policy to prevent macroeconomic crises, largescale reforestation to prevent natural disasters, or public health campaigns to reduce the incidence of illness. Furthermore, it may also include measures designed to better equip the population to protect themselves, such as building a more solid asset base through land distribution and housing provision, as well as access to credit and insurance markets. Social protection programmes may also include interventions designed to help the population cope with risk and poverty, such as social assistance, social funds, cash transfers, and welfare programmes. 
- the federal and state employees, statutory bodies, local authorities, civil servants, members of the judiciary, the military, and former members of parliament and state legislative assemblies. Benefits of this scheme include those relevant to employment injury, disability, gratuity payment upon retirement, and dependents' pension in the event of death while in service and death after retirement. The Public Service Pension Scheme is under the responsibility and is fully financed by the federal government, and there is no contribution made by the employees. The funding of the scheme is through tax revenues.

While the Public Service Pension Scheme oovers all public employees, the majority of employees outside the civil service are covered by a statutory provision fund that provides retirement benefits under the Employee Provident Fund Act. In terms of coverage, the EPF covers all private sector employees, the public sector employees who opted for EPF (non-pension), and others who voluntarily opted to contribute to the scheme. SOCSO on the other hand is operating under the principle of social insurance and Dooling of risks and finances. The SOCSO scheme provides protection to workers for contingencies such as injury, including commuting accidents, occupational diseases, invalidity, and death. The benefits offered include medical, temporary isablement, permanent disablement, dependents benefit, funeral, rehabilitation, invalidity, and survivors' pension.

It should be noted that the existing institutions - the Public Service Pension Scheme, the Employees Provident Fund (EPF) and the - Social Security Organisation (SOCSO) are inadequate in providing social protection in the Wider sense. Perspective on social protection is only limited to retirement and employment injury and invalidity. Besides, these three institutions only cover the formal sector. They do not cover those employed in the informal sector. This raises the question of coverage of these institutions in providing social protection since those employed in the informal sector are quite large in number. ${ }^{4}$ Most of them are exposed to potential risks from natural, social and economic hazards. They are also most likely to have low educational attainment and skills. Thus, when exposed to natural, social, or economic hazards, particularly the low-income group amongst them, their income is most likely to fall and they might get into transitory poverty. For those who are in the chronic poverty category, their situation might be worst. It is clear that the three institutions above do not have much to offer in coping with such situations. Furthermore, these institutions also do not really tackle the risk associated with globalisation, given the fact that the Malaysian economy is highly integrated into the global market. The existing institutions appear not to have addressed the needs of those who have been adversely affected from the exposure of the economy to the global market, particularly with regards to unemployment and poverty.

\section{THE IMPACT OF GLOBALISATION ON UNEMPLOYMENT AND POVERTY}

There is no doubt that global market uncertainty and volatility arising from globalisation affects economic growth and job security. ${ }^{5}$ Even though one might argue that large external shocks do not occur frequently, still, since Malaysia is an open economy, the impact of globalisation on the labour market (and unemployment) could still be felt through the changing market structure. A changing global environment raises the needs for economic structural change (adjustment), since in global market competition, those economies that adjust swiftly with the changing environment will be rewarded with faster economic growth, while those that do not will suffer from economic slowdown. The changing structure of the economy on the other hand alters the composition of labour demand (Mazumdar, 1991). Besides, globalisation also has created a new economy, whereby it is much more knowledge-based as compared to the past (Tanzi, 2002). Thus, one could expect that not only job opportunities in the manufacturing and services sectors will be higher, but the demands for white collars (skilled-workers) will also be greater.

In fact, globalisation may force continuous structural adjustments to the economy. As a 
consequence, job destruction and job creation will be a common feature of a globalised economy since more jobs will be created in new and expanding sectors, and jobs will be lost in the shrinking sectors. Unemployment therefore could persist continuously as a result of globalisation and might be insensitive to changes in the economic growth rates. In other words, globalisation creates structural unemployment. From this perspective, unemployment in a globalised economy might no longer be demand-related (represented by GDP growth) per se, but might also be structurallyrelated. The point here is that globalisation tends to make unemployment as a permanent feature - in the economy.
The above assertion is consistent with the trend in employment in the Malaysian economy. Table 4 shows that there is a clear declining trend in agricultural employment, but at the same time employment in the manufacturing and services are on the rise. These sectors - manufacturing and services - employ many professionals and administrative (managerial) employees, but this does not mean that white-collar jobs are any safer in the expanding sectors. On the contrary, job insecurity is experienced across all types of occupations as shown in Table 5. Unemployment in Malaysia is no longer constrained to the bluecollar workers, but has also affected the whitecollar workers as well. ${ }^{6}$

\section{Table 4}

Trend in Employment in Malaysia by Sectors (Percentage)

\begin{tabular}{|c|c|c|c|c|c|c|c|c|}
\hline Sector & 1970 & 1975 & 1980 & 1985 & 1990 & 1995 & 2000 & 2005 \\
\hline $\begin{array}{l}\text { Agriculture, Forestry, } \\
\text { Livestock \& Fishing }\end{array}$ & 53.2 & 47.6 & 39.7 & 31.3 & 27.8 & 17.9 & 15.2 & 12.9 \\
\hline Mining \& Quarrying & 2.6 & 2.2 & 1.7 & 0.8 & 0.6 & 0.5 & 0.4 & 0.4 \\
\hline Manufacturing & 9.0 & 11.1 & 15.6 & 15.2 & 19.5 & 25.9 & 27.6 & 28.8 \\
\hline Construction & 2.7 & 4.0 & 5.6 & 7.6 & 6.4 & 8.5 & 8.1 & 7.0 \\
\hline $\begin{array}{l}\text { Finance, Insurance, } \\
\text { Real Estate \& Business } \\
\text { Services }\end{array}$ & 12.3 & 13.0 & 13.4 & 3.5 & 3.5 & 4.8 & 5.5 & 6.7 \\
\hline $\begin{array}{l}\text { Transport, Storage \& } \\
\text { Communication }\end{array}$ & 4.0 & 4.5 & 4.1 & 4.3 & 4.3 & 5.0 & 5.0 & 5.8 \\
\hline Government Services ${ }^{1}$ & 11.9 & 12.9 & 14.4 & 14.6 & 12.8 & 11.0 & 10.6 & 9.7 \\
\hline Other Services ${ }^{2}$ & 4.3 & 4.8 & 5.6 & 22.6 & 25.1 & 26.5 & 27.6 & 28.8 \\
\hline
\end{tabular}

Source: Ministry of Finance (Various Issues), Economic Report.

${ }^{1}$ Includes public administration, health, education and defence.

${ }^{2}$ Includes electricity, gas and water, wholesales and retail trade, hotels and restaurants, and other services.

In fact during the financial crisis, of those retrenched between $1^{\text {st }}$ of January and $26^{\text {th }}$ July $1998,17 \%$ were from the professional and technical category, and $8 \%$ from the administrative category (MIER, 2002). Furthermore, the sector that experienced the most number of retrenchments was manufacturing (53\%), followed by distributive trades (12.4\%), construction (11.1\%), and finance, insurance and real estates $(7.9 \%)$ as shown in Table 6. On the whole, these sectors perform primarily urban-based activities. 
Table 5

Unemployed Workers by Occupational Groups

\begin{tabular}{ccccccc}
\hline Year & Production & Agricultural & Services & Clerical & $\begin{array}{c}\text { Professional } \\
\text { Technical }\end{array}$ & Others \\
\hline 1975 & 59.1 & 4.6 & 7.5 & 24.1 & 4.2 & 0.6 \\
1983 & 37.6 & 1.9 & 6.2 & 47.1 & 5.5 & 1.3 \\
1986 & 35.7 & 1.6 & 5.2 & 42.8 & 12.0 & 2.7 \\
1987 & 31.1 & 1.3 & 4.8 & 39.8 & 14.1 & 2.9 \\
1995 & 32.1 & 0.4 & 2.6 & 51.6 & 10.3 & 3.0 \\
1997 & 34.3 & 0.3 & 1.8 & 46.6 & 11.8 & 5.2 \\
1998 & 29.5 & 0.3 & 2.5 & 44.1 & 15.8 & 7.8 \\
1999 & 25.1 & 0.2 & 1.6 & 46.9 & 16.8 & 9.4 \\
2000 & 25.1 & 0.3 & 1.5 & 46.6 & 16.0 & 10.5 \\
2001 & 20.5 & 0.3 & 1.7 & 44.9 & 23.3 & 9.3 \\
2002 & 20.3 & 0.3 & 1.6 & 49.4 & 21.0 & 7.3 \\
2003 & 22.6 & 0.3 & 1.8 & 50.0 & 19.1 & 7.2 \\
2004 & 9.5 & 1.1 & 4.2 & 35.6 & 41.8 & 7.7 \\
\hline
\end{tabular}

Source: Ministry of Finance (Various Issues), Economic Report.

Table 6

Retrenchment in 1998 and First Quarter 1999

SECTOR

Retrenchment in $1988 \quad \begin{gathered}\text { Retrenchment in first } \\ \text { quarter of } 1999\end{gathered}$

\begin{tabular}{cccc}
\hline Number & \% share & Number & $\%$ share \\
\hline 5108 & 6.1 & 358 & 3.1 \\
877 & 1.1 & 298 & 2.6 \\
45151 & 53.8 & 6336 & 55.3 \\
9334 & 11.1 & 1269 & 11.0 \\
& & & 27.8 \\
1 & - & 0 & 0 \\
10434 & 12.4 & 1301 & 11.4 \\
6596 & 7.9 & 1040 & 9.0 \\
2007 & 2.4 & 189 & 1.7 \\
4242 & 5.1 & - & - \\
- & - & 661 & 5.8 \\
115 & 0.1 & 2 & - \\
83865 & 100.0 & 11454 & 100.0 \\
\hline
\end{tabular}

Source: MIER (2002). 
Besides, there is also the problem of job mismatch that is inherent in the Malaysian labour market. For instance, even though the number of those looking for jobs exceed the number of job vacancies, job vacancies are never being fully filled. Table 7 shows that only about $20 \%$ of those unemployed registered with the Manpower Department of the Ministry of Human Resource have found new jobs during 1998 to $2000 .{ }^{7}$ At the same time, fresh university graduates find it difficult to get employment upon graduation, which most likely indicate the existence of job mismatch in the labour market. ${ }^{8}$

The above discussions lead us to the point that unemployment in Malaysia is to a certain degree, structural-related. Figure 2 shows the real growth rates of GDP in Malaysia. It does not seem to have a clear systematic relationship with unemployment rates.

Table 7

Registered Unemployed, Vacancies, and Placements, 1998-2000

\begin{tabular}{cccccc}
\hline & \multicolumn{3}{c}{ New Registered Unemployed } & \multicolumn{2}{c}{ Placements } \\
\cline { 2 - 6 } & Number & $\begin{array}{c}\text { \% of total } \\
\text { unemployed }\end{array}$ & $\begin{array}{c}\text { Registered } \\
\text { vacancies }\end{array}$ & Number & $\begin{array}{c}\text { \% of registered } \\
\text { unemployed }\end{array}$ \\
\hline 1998 & 114,190 & 35.9 & 69,091 & 20,864 & 18.3 \\
1999 & 122,920 & 38.7 & 108,318 & 23,095 & 18.8 \\
2000 & 112,835 & 35.5 & 123,484 & 24,738 & 21.9 \\
\hline
\end{tabular}

Sources: Ragayah, Lee Hwok Aun and Saidah (2002).

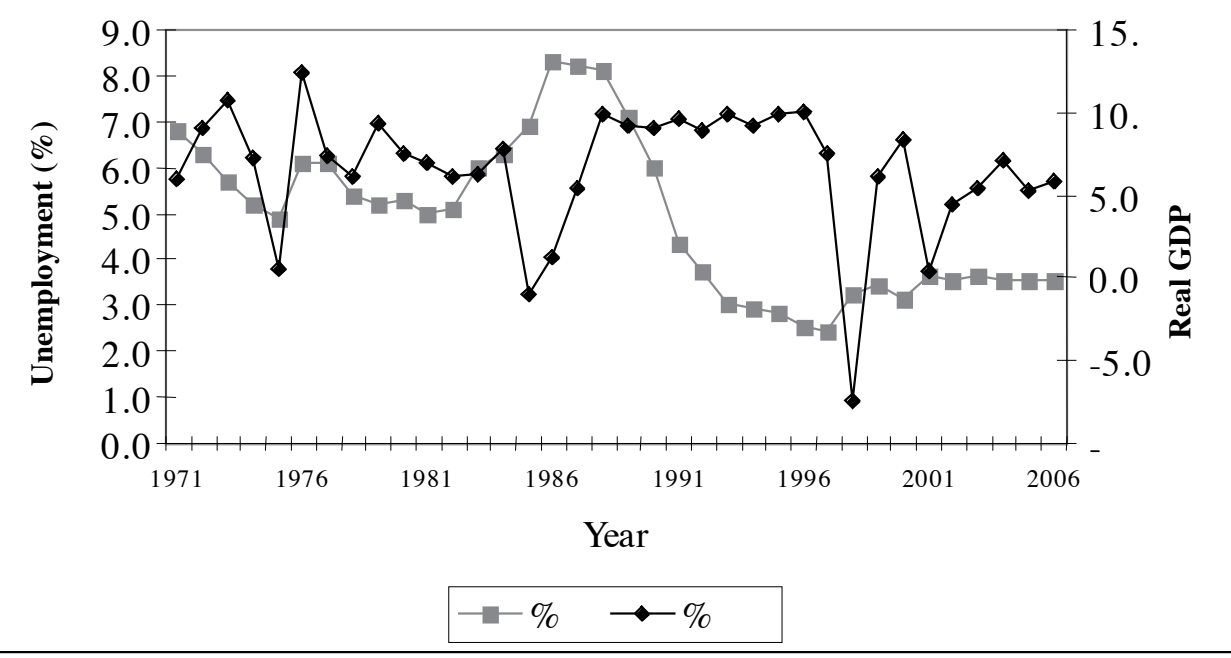

Sources: Ministry of Finance (Various Issues). Economic Report.

Figure 2

Unemployment and real growth rates, 1971-2006 
Table 8

Malaysia: Incidence of Poverty and Number of Poor Households, 1995, 1997 and 1999

\begin{tabular}{|c|c|c|c|c|}
\hline \multirow[b]{2}{*}{ YEAR } & \multicolumn{2}{|c|}{ Incidence of Poverty } & \multicolumn{2}{|c|}{ Incidence of Hardcore Poverty } \\
\hline & $(\%)$ & No. ('000) & $(\%)$ & No. (‘000) \\
\hline \multicolumn{5}{|l|}{1970} \\
\hline Total & 52.4 & 1000.0 & - & - \\
\hline Rural & - & - & - & - \\
\hline Urban & - & - & - & - \\
\hline \multicolumn{5}{|l|}{1990} \\
\hline Total & 17.1 & 574.5 & 3.9 & 137.1 \\
\hline Rural & 21.1 & 492.5 & 5.2 & 121.6 \\
\hline Urban & 7.1 & 82.0 & 1.3 & 15.5 \\
\hline \multicolumn{5}{|l|}{1995} \\
\hline Total & 8.7 & 365.6 & 2.1 & 88.4 \\
\hline Rural & 14.9 & 281.8 & 3.6 & 68.3 \\
\hline Urban & 3.6 & 83.8 & 0.9 & 20.1 \\
\hline \multicolumn{5}{|l|}{1997} \\
\hline Total & 6.1 & 274.2 & 1.4 & 62.4 \\
\hline Rural & 10.9 & 221.8 & 2.5 & 51.8 \\
\hline Urban & 2.1 & 52.4 & 0.4 & 10.6 \\
\hline \multicolumn{5}{|l|}{-1999} \\
\hline Total & 7.5 & 360.1 & 1.4 & 66.0 \\
\hline Rural & 12.4 & 271.0 & 2.4 & 52.1 \\
\hline Urban & 3.4 & 89.1 & 0.5 & 13.9 \\
\hline \multicolumn{5}{|l|}{2002} \\
\hline Total & 5.1 & 267.9 & 0.5 & 52.9 \\
\hline Rural & 11.4 & 198.3 & 2.3 & 40.3 \\
\hline Urban & 2.0 & 69.6 & 0.4 & 12.6 \\
\hline \multicolumn{5}{|l|}{$2004^{a}$} \\
\hline Total & 5.7 & 311.3 & 1.2 & 67.3 \\
\hline Rural & 11.9 & 219.7 & 2.9 & 53.2 \\
\hline Urban & 2.5 & 91.6 & 0.4 & 14.1 \\
\hline
\end{tabular}

- Note: a Figures for 2004 is based on EPU's 2005 methodology, i.e. a revised version of calculating poverty. Source: Malaysia $(1991,1996,2001,2006)$.

For example, in 1983 and 1984 the unemployment rates were rising even though the growth rates were also rising. In fact, unemployment kept rising even before the downturn of GDP in 1985. During the recovery years of 1986-1987, the strong rises in GDPs were not matched by a big decline in unemployment rates. Unemployment rates seemed to show resistance of declining. The reverse occurred in the period of 1988-1997 when the growth rates seemed to stabilise, but unemployment seemed to decline. Even during the East Asian economic crisis, the Iraqi war, and SARS outbreak, unemployment rates had shown resistance to change although growth rates had shown big fluctuations. The fact that there were periods when unemployment was not quick to respond to GDP growth suggests that structural unemployment exists. ${ }^{9}$ Globalisation tends to make unemployment as a permanent feature in many economies. ${ }^{10}$ 
Besides making unemployment become a permanent feature in many economies, globalisation also has a significant impact on poverty. With regards to the impact of globalisation on poverty, it is the low-income groups that are very vulnerable to any instability arising from globalisation, especially farmers that are involved in export commodities such as oil palm, rubber, and cocoa, as well as the urban low-income workers. Declining commodity prices, retrenchments, and pay-cuts will result in reduction in income amongst the low-income groups, and they might fall into poverty. Thus, globalisation affects those who are both the chronic and transitory poor.

- The economic crisis in 1997 for instance gave clear evidence of the impact of globalisation on poverty. From 1970 to 1995 , poverty incidence in Malaysia, as indicated by the head-count ratio, declined significantly from $52.4 \%$ in 1970 to $9.3 \%$ in 1995. Rural and urban poverty also exhibited - a significant reduction. From 1995 to 1997, it could be concluded that the incidence of poverty in Malaysia had declined, as indicated by the fall in the head-count ratio from $9.3 \%$ in 1995 to $6.8 \%$ in 1997, as shown in Table 8. However, after the economic crisis in 1997-1998, there had been a rise in the number of poor households as well as - poverty incidence in Malaysia. The total incidence of poverty increased from $6.8 \%$ in 1997 to $8.1 \%$ in 1999. Both rural and urban areas recorded an increase in poverty incidence from $11.8 \%$ to $13.2 \%$ and from $2.4 \%$ to $3.8 \%$, respectively. Interestingly however, the overall incidence of hardcore poverty remained the same between 1997 and 1999 at $1.4 \%$. Nevertheless, the absolute number of hardcore poor households increased from 67,500 to 71,100 .

Generally speaking, the rural poor may find it easier to cushion the impact of the crisis by diversifying their income sources in agricultural and other activities. It is the urban poor that were much more badly hit by the economic crisis since the crisis affected the urban-based activities the most, particularly the industrial and financial sectors. What is more worrying is the fact that there emerged a new class of poor people, namely "the new poor", resulting from the recent economic crisis (MIER, 2002). The new poor refers to the highly leveraged households that were hit by the financial crisis, including the middleincome professionals with mortgage payments on their house and car, as well as the self-employed with business loans. Although the majority of the professionals and self-employed would have had savings to tide them over, a significant number lost their assets. Thus, the adverse impact of globalisation on the poor, as well as on unemployment, demands a new thinking on social protection as the existing institutions appear inadequate to cater for the needs of those adversely affected by globalisation. The argument for the need of a new perspective and thinking on social protection is discussed below.

\section{THE NEED FOR A NEW PERSPECTIVE ON SOCIAL PROTECTION}

Generally speaking, while countries could succeed in achieving growth and development from the opportunities offered by globalisation, as the East Asia countries did, globalisation also entails risks, and hence economic insecurity. The recent Iraqi war and SARS epidemic also highlighted the many risks that countries will face in the new globalised world. The East Asia economic crisis in 1997-98 for example has caused GDP and wages in affected countries to fall dramatically, while unemployment and poverty to rise. The vulnerability and difficulty experienced by the population in these countries to cope swiftly to external shocks highlighted the inadequacies of the current social protection policies to absorb or dampen these shocks. Social protection that is highly informal and implicit in arrangement, i.e. mainly depends on the family and to a certain extent the non-governmental organisations (NGOs), as well as indirect protection that was promoted through high economic growth, become no longer tenable.

The process of globalisation, has gradually undermined social integration and norms (Rodrik, 1997), as well as the effectiveness of the traditional-informal social protection system. ${ }^{11}$ As argued by North (1990), new systems and institutions must be put in place to complement the 
quickly deteriorating informal systems in order to reduce future risks to the population. Otherwise, if institutional change does not occur in the face of a changing environment, then the institution may no longer be sufficient and relevant, and consequently will become impediment for growth and development. ${ }^{12}$ In addition, the current economic environment is different from the previous one. Previous globalisation was spurred by technological change and mass migrations. On the other hand, the current wave of globalisation has created a new economy whereby it is much more knowledge-based as compared to the resource-based economy of the past. As a result, these ongoing changes will subject the existing institutions, such as the social protection systems that were created under the different environment, significant stress (Tanzi, 2002).

(1) Undoubtedly, the existing social Institutions are inadequate to face the challenges of globalisation. A rethinking on social protection currently embraced in Malaysia is more urgently needed given the fact that unemployment will become a permanent feature in many open economies. As being mentioned earlier, the impact of globalisation cuts across all social groups and all categories of workers - the white collar as well - as the blue collar, urban as well as rural folks and has also created a new class of poor people, i.e. the new poor (MIER, 2002). Thus, there is need for a change of mindset, particularly by he government, when looking at the provision of social protection, especially with regards unemployment insurance. ${ }^{13}$ Policies toward - protecting the unemployed should not be ad-hoc in nature, i.e. policies should be in place before problems occur, not after. ${ }^{14}$ For instance, some kind of unemployment insurance scheme should be in place to cater for the needs of those unemployed due to structurally-related factors. ${ }^{15}$ This is important since globalisation has exposed Malaysia as well as other East Asian countries to external shocks more than ever.

The financial crises of the past few years, such as those in Mexico in 1994-95, in South East Asia in 1997-98, and in Brazil and Russia in 1998, have been blamed largely on the process of globalisation. Through its impact on short-term capital movements, globalisation has increased the likelihood of financial crises and economic instability, and hence raises the need for the government to seriously pursue a more efficient and effective social protection system than in the past. A good social protection system will help the economy to be more flexible and to adjust accordingly to shocks originating from the global market. In this regard, there is a need to look at the Unemployment Insurance Programme (UIP) as a human investment policy. UIP should include not just unemployment benefits, but must also include programmes for job skill development, and programmes to promote and maintain employment.

As an economy that is highly integrated with the global market, the provision of a formal social protection system is vital if Malaysia is to enhance her competitiveness, reduce economic insecurity and risks, as well as to sustain her economic prosperity from globalisation. However, the provision of a formal social protection system seems to be difficult to realise since there is a lack of political will on the part of the government. This was made clear in a statement (concerning unemployment benefits) by the ex-Prime Minister, Mahathir Mohammed;

\section{...this method will only wreck the economy. When unemployed is paid an allowance, then many will choose not to work. The Government will need to allocate money for dole which can only be done through raising taxes on the unemployed... Of course the production costs for goods will increase, so will the cost of living. So, each time dole is raised, taxes follow suit and the cost for manufacturing goods will only reduce our competitiveness in the world market (New Straits Times, 10/06/99).}

However, the above comment appears to be a narrow perspective of social protection, i.e. social protection that is viewed merely as compensation or remunerative aid to the unemployed or the 
poor. We argue that social protection must not be looked at from the above standpoint. Social protection must be viewed in its broadest sense as defined by Holzmann and Jorgensen (2000). Social protection must be viewed in terms of Social Risk Management (SRM), where the strategies include the prevention, mitigation, and coping mechanisms toward risks and vulnerability. This entails formulation of measures designed not only to compensate or remunerate aid to the unemployed or the poor (so that they can cope with the adverse situation), but must also include measures to raise their capabilities or potentials. Thus, spending on social protection must be viewed principally as investment on human capital rather than as public spending in providing cash and/or in-kind transfers to the unemployed or the poor. In view of that, we believe that the state has to play a key role in constructing a social protection system that is modern and relevant to the people.

\section{CONCLUSION}

The Malaysian economy is an open economy

- that is highly integrated with the global economy. Besides, it has also undergone a very significant structural change, which was induced to a large extent by the forces of globalisation itself. From basically an agricultural-based economy, her economy is now more dependent on urban and industrial-based activities, particularly the manufacturing and services sectors.
Indeed, Malaysia's rapid economic growth and development could be attributed to her openness to the global market, specifically through export and outward oriented policies. Nonetheless, the change in the economic structure, as well as the integration of Malaysian economy to the global market, has also brought about economic instability and insecurity, particularly with regards to unemployment and poverty. The changing economic environment, i.e. the instability and insecurity arises from globalisation, demands changes to the role of existing institutions and also creates the need for new institutions.
Here, we argue that globalisation of the Malaysian economy has made the existing social institutions, specifically with regards to social protection, become inadequate and unable to cope with the changing needs of the population. A more formal social protection system is needed given the fact that the traditional-informal social protection system has eroded following the changes in the socio-economic structure that is driven by globalisation. However, it appears that the government is less inclined with the idea of formal social protection since their perspective on social protection seems to be a narrow one. Thus, there is a need to advocate a new perspective and thinking on social protection, i.e. looking at social protection primarily as human capital investment to prevent, mitigate, and cope with risks and vulnerabilities, rather than simply as public spending on cash or in-kind transfers. If Malaysia is to face the challenges of globalisation, Malaysia needs, more than ever, institutions that are modern and relevant to the changing economic environment, so that the institutions can play their roles effectively to facilitate growth and development, as well as enhance competitiveness in the economy. The state has to play a leading role in developing a formal, modern, and relevant social protection system.

\section{END NOTES}

1 Globalisation has many different facets economic,cultural,political, andenvironmental dimensions. In this paper, we refer to economic globalisation, i.e. globalisation that is viewed as the increasing integration of the world's economies through the extension of international trade and finance, movement of labour, technology and knowledge across state borders. Globalisation is defined as "increasing goods and factor market integration, whereby a completely integrated market is characterised by the absence of any impediments in international mobility of - as the case may be - commodities, services, and the production factors capital, labour and technology", 
(Shulze \& Ursprung, 1999, p. 301), or “the process of growing interconnection between national economies. It involves the increasing integration of more and more nations and economic actors into market relationships" (Hirst \& Thompson, 1992, p. 358).

2 The term social protection is frequently used as an alternative to social security and social safety net. Of the two terms, social protection is the most commonly used internationally. The term social safety net appears to have less precise meaning; some people use it to mean the whole set of programmes and policies, others use it to refer only to welfare programmes targeted to the poor. On the other hand, the term social security is generally used to refer to the comprehensive mechanisms and coverage in high-income countries, and less - applicable to new areas such as community and area-based schemes which exist in developing countries (Asian Development Bank, 2001).

See Bank Negara Malaysia (1994; 1999; 2002; 2003), Economic Report (2002), and Malaysia (1991).

While there is no official categorisation of the informal sector in Malaysia, nevertheless it could be referred to the self-employed, i.e. those own account and unpaid family workers, including petty traders, food and merchandise hawkers, and insurance agents. In 1999, there were 427,800 male and 253,900 female workers that were self-employed in the urban areas, while for the rural areas, the figures are much higher, that is 897,600 and 453,800 for male and female workers respectively (Malaysia, 2001). Most of the self-employed in the urban areas are found in the wholesale and retail trade, and service sectors, while the self-employed in the rural areas are found in agriculture, forestry, and fishing . Besides, the self-employed, including the unpaid family workers, represent about $11 \%$ of the total workforce (Ragayah, Lee Hwok Aun, \& Saidah, 2002, p.144). It is most likely that many of those who are self-employed do not have access to formal protection, or do not involve themselves in such programmes. Registering as EPF contributors for example, requires them to declare their income that they may not wish to disclose.

5 During the Asian economic crisis, some 18,863 Malaysians lost their jobs in 1997, while another 83,865 people lost theirs in 1998 , an increase of 345 percent (Ishak, 2000).

6 This is quite similar to the findings by Keltzer (1998) on job displacement in the US. During the period of 1984-1996, she found that when looking at the level of education, less educated workers are much more likely to be displaced than more educated workers. However, more workers with college degree lost their jobs in 1990s than in 1980s. Again, when looking at job displacement by occupation, although the job loss rates are higher for craftsmen, operatives and labourers than workers in other occupational groups, in 1990s however, the burden of job loss has spread more evenly across occupations. The rates of job loss for managers, professional and technical workers, and sales and administrative workers show little cyclical pattern, that is they have not fallen with US economic recovery since 1992. In another study by Murphy and Topel (1989), they concluded that not only has the unemployment in the US increased in all major industries, in all age, and schooling groups, and in all major regions of the country, but unemployment is also becoming more longterm in nature, and is uniform across sectors, regions, and demographic groups.

7 According to the Malaysian Human Resource Minister, Dr Fong Chan Onn, out of a total of 9,804 people registered for jobs with the Labour Department in the first three months of year 2003, only 1,360 of them were allocated jobs although there are 11,360 vacancies registered with the department. He added that the problem of candidates having mismatched qualifications for the jobs is the most prevalent 
factor for the poor performance (The Star, 26/05/03).

8 In 2003, there were around 50,000 unemployed graduates nationwide (The Star, 13/05/03). As a result, the government has spent a total of RM130 million since 2001 under the Graduate Training Scheme to provide more skills for unemployed graduates, and has allocated another RM50 million for the programme this year (The Star, 5/9/03).

See Mazumdar (1991) for a more detail study on the relationship between unemployment and real GDP in Malaysia.

${ }^{10}$ With regards to the structural unemployment, Yap (2002) acknowledged that in Singapore "there is evidence that structural unemployment is rising not only among the older workers but also among the bettereducated and among professionals, managers, and associated professionals. Factors contributing to structural unemployment in Singapore include the limitation of being a small city-state with an ageing population and labour force, skills-vacancy mismatch (not just among the older workers but also among the young and professionals), and the inflexible mindsets and expectations of employers as well as job seekers. The problem of structural unemployment is likely to be sticky as the population and workforce grows progressively older, requiring radical mindsets changes and changes in the education system as well." In this regard, the problem of graduate unemployment that has plagued Malaysia since 1997 is evidence to this irresponsiveness although the growth rates have improved much after the Asian economic crisis. What this fact shows is that, a constantly changing global environment will keep on altering the composition of demand, which necessitates for structural adjustment.

${ }^{11}$ For instance, expansion of market has made people more individualistic in nature, with less social ties. Due to pressures to survive in a market economy, in many households both the husband and wife are now working. Thus, parents can no longer rely on their children to look after them in their old age.

${ }^{12}$. North (1990) argued that institutions do matter to economic growth and development. To sustain economic growth and development in a rapidly changing environment, which nowadays is brought about by globalisation forces, institutions must evolve accordingly, otherwise rigid or obsolete institutions will become impediment for growth and development.

${ }^{13}$ Because of the perceived negative stigma, the Korean Unemployment Insurance was renamed Korean Employment Insurance. Malaysia, like many other Asian countries, does not have a comprehensive social protection programme for unemployed workers. In fact, currently there are only five Asian countries that have some kind of unemployment insuranceunemployment assistance (UI-UA) schemes; namely Hong Kong, Japan, Korea, China, and Bangladesh (Vroman, 1999).

${ }^{14}$ In Malaysia, retrenched workers are usually given retrenchment compensation as stipulated in the Employment Act 1955 and Employment (Termination and Lay-off Benefits) Regulation 1980. Although the Malaysian Trade Union Congress (MTUC) has proposed a plan to set up a National Retrenchment and Unemployment Fund to the government in 1997, no serious effort has been made to realise that idea.

${ }^{15}$ Singapore for instance has proposed some kind of unemployment compensation scheme similar to that introduced by South Korea after the financial crises. This is because, according to Yap (2002), the current social safety net in Singapore is no longer adequate to protect the workers since unemployment is expected to be a long-term phenomenon and will affect both skilled and unskilled workers alike, as well as fresh graduates. 


\section{REFERENCES}

Asian Development Bank, (2001). Social protection strategy: Manila.

Bank Negara Malaysia, (1994). Money and banking in Malaysia (35 th anniversary edition 1959-1994). Kuala Lumpur: Bank Negara Malaysia.

Bank Negara Malaysia, (1999). The Central Bank and the financial system in Malaysia $-a$ decade of change. Kuala Lumpur: Bank Negara Malaysia.

$\square$

Bank Negara Malaysia, (2002). Laporan Tahunan 2002. Kuala Lumpur: Bank Negara Malaysia.

Bank Negara Malaysia, (2003). Laporan Tahunan - 2003. Kuala Lumpur: Bank Negara Malaysia.

Birdsall, N., (2000). Building a market-friendly middle class. Remarks made at the Annual World Bank Conference on Development Economics, Washington, DC, April 18, 2000, 109-115.

Hirst, P., \& Thompson, G. (1992). The problem of 'globalisation': International economic relations, national economic management and the formation of trading blocs. Economy and Society, 21(4).

- Holzmann, R., \& Jorgensen, S. (2000). Social risk management: A new conceptual framework for social protection and beyond. Social Protection Discussion Paper No. 0006: World Bank.

Ishak, Shari. (2000). Globalisation and economic disparities in East and Southeast Asia: New dilemmas. Third World Quarterly, 21(6), 963-975.

Keltzer, L. G. (1998). Job displacement. The Journal of Economic Perspectives, 12(1), 115-136.
Malaysia,(1991). The Second Outline Perspective Plan, 1991-2000. Kuala Lumpur: National Printing Department.

Malaysia, (1996). Seventh Malaysia Plan, 19962000. Kuala Lumpur: National Printing Department.

Malaysia, (2001). Eight Malaysia Plan, 20012005. Kuala Lumpur: National Printing Department.

Malaysia, (2006). Ninth Malaysia Plan, 20062010. Kuala Lumpur: National Printing Department.

Mazumdar, D. (1991). Malaysian labour markets under structural adjustment. Policy Research and External Affairs Working Paper No. WPS 573: World Bank.

MIER, (2002). Linking globalisation and poverty: The social impact of the Asian crisis on Malaysia. Paper presented at the MIER Conference on Poverty Alleviation and Social Stability, Malaysian Institute of Economic Research (MIER), Kuala Lumpur, 22-23 October.

Murphy, K., \& Topel, R. (1989). The evolution of unemployment in the United States: 19681985. NBER Working Paper No. 1209, National Bureau of Economic Research.

North, D. C. (1990). Institutions, Institutional Change and Economic Performance, New York: Cambridge University Press.

Ragayah, Hj. Mat Zin, Lee Hwok Aun \& Saidah Abdul-Rahman, (2002). Social Protection in Malaysia. In Adam, Hauff \& John (eds.) Social protection in Southeast and East Asia, Singapore: Friedrich Ebert Stiftung.

Rodrik, D. (1997). Has globalisation gone too far? Washington D.C.: Institute for International Economics. 
Rodrik, D. (1998). Why do more open economies have bigger governments? Journal of Political Economy, 106(5), 997-1032.

Schulze, G. G., \& Ursprung, H. W. (1999). Globalisation of the economy and the nation state. The World Economy, 22(3), 295-352.

Tanzi, V. (2002). Globalisation and the future of social protection. Scottish Journal of Political Economy, 49(1), 116-127.

The New Straits Times, (1999). PM says 'no' to dole as wider safety net. June $10^{\text {th }}$.

The Star, (2003). NEAC to study jobless grad problem. May $13^{\text {th }}$.
The Star, (2003). Over 9,800 register with department for jobs. May $26^{\text {th }}$.

The Star (2003). RM50m more for training. September $5^{\text {th }}$.

Vroman, W. (1999). Unemployment and unemployment protection in three groups of countries. Social Protection Discussion Paper No. 9911: World Bank.

Yap, Mui Teng, (2002). Employment insurance: A safety net for the unemployed. Report prepared for the Remaking Singapore Committee on Beyond credit card-income distribution, social safety nets, sports and arts. The Institute of Policy Studies, Singapore. 